\title{
The Impacts of AFTA on International Trade in Laos
}

\author{
Outhai KEOCHAIYOM*
}

\begin{abstract}
Laos joined ASEAN in 1997 and has practiced the Common Effective Preferential Tariff (CEPT) scheme under ASEAN Free Trade Area (AFTA) since 1998. To estimate the effects of AFTA on international trade in Laos, this paper has built a gravity model to analyze the specific effects of AFTA on aggregate international trade volume, import and export in Laos by using bilateral trade data between Laos and 29 partner countries during 2000 and 2012. Binary variables and the size of economy of AFTA are chosen to be the two variables reflecting the effect of AFTA on international trade of Laos. Results indicate that AFTA has positive effects on aggregate international trade volume and import while negative effects on export in Laos.
\end{abstract}

Key Words: Laos;AFTA; international trade; gravity model.

JEL Classification: F14, F15, R11

\footnotetext{
* School of Economics and Trade, Hunan University, Changsha 410079, China Outhai2@hotmail.com
} 


\section{Introduction}

Lao People's Democratic Republic is one of the landlocked countries in Southeast Asian region with a population of over 6.5 million people in 2012 and a land area of 236.800 square kilometers, it shares the border with China to the north, Vietnam to the east, Cambodia to the south, Thailand to the west and Myanmar to the northwest. In 1975, the declaration of established Lao People's Democratic Republic lead Laos to be governed under a socialist system and the state adopted a central planned economic system, centralizing investment, production, trade and pricing that created barriers to internal and foreign trade. In 1986, the New Economic Mechanism (NEM) was introduced and as a result, both private and foreign investments were promoted as well as international trade. Laos was accepted to be a full member of ASEAN in July 1997 and participated in the ASEAN Free Trade Area in January 1998.

The aim of this paper is to estimate the effects of AFTA on international trade in Laos from three aspects: (1) the effect of AFTA on aggregate international trade volume in Laos; (2) the effect of AFTA on import in Laos; (3) the effect of AFTA on export in Laos. A gravity model is chosen to analyze the panel data of bilateral trade data between Laos and 29 partner countries from 2000 to 2012.

\section{Literature Survey on Laos' Regional Economic Integration}

\subsection{General Issues}

Lots of researches have discussed AFTA from different views since the 1950s. American economist Jacob Viner (1950) published an article "The customs union issue". He proposed the concept on "Trade creation" and "Trade diversion" which became the basis concept of the FTA. Early researches pointed out that intra-ASEAN trade would increase and trade creation effect could be stronger than trade diversion effect with tariff preference. Naya(1980),Janamitra Devan(1987), Peal Imada (1993) and Bende-Nabende (1999) showed that AFTA had investment effect and brought benefits to developed countries of ASEAN only. Junlin Li, Dongmin Yao and Xiaochen Xu (2012) used panel data to analyze the integration inside intra-ASEAN member countries during 2000-2009. The result indicated that trade between intra-ASEAN had decreased but the trade between ASEAN and other countries had increased. Furthermore, they also found that there was a 
unique difference from other regional economic integration groups. Inside ASEAN, there were two significant different groups, strong economy group and weak economy group, which were uncoordinated, this lead to a differentiation to occur inside ASEAN.

However, research on the effect of AFTA on Laos is comparatively less and new. Most of the research consists of discussion papers, like ADB or World Bank working paper series. Phouphet KYOPHILAVONG (2004) argued that taking part in AFTA causes a larger increase in import than export, meaning that Laos will face a trade deficit problem. But some scholars have showed a different opinion. Although Laos has a weak economy, undeveloped technology, low products quality and local business people also have less experience, AFTA would bring negative impacts to local businesses and industries, like decreasing government revenue. There are also some benefits such as stronger political status, larger attraction to foreign investment, higher government income, more economic support from membership countries and wider range of products with lower price for consumer (Keo Vongxay, 2006). Later, Souksavanh Vixathep (2011) did research on the structure of external trade of Laos during 1985-2005. Results showed: (1) exports mostly concentrated on agricultural products and crude natural resources; (2) the labor-intensive garment industry had gained competitiveness and the mining industry (copper) tended to form competitiveness; (3) during each research period, the production structure of exports did not change significantly and trade diversification was low; (4) specialization tended to occur in the simple product lines within an industry. Yin Hua and Soulya Phoulaxavong (2012) applied the gravity model to analyze the impact of ACFTA on Laos- China trade from 1990 to 2009. The research showed that the positive effect of ACFTA on the export from Laos to china was significant while its positive effect on the import of Laos from China was insignificant. Leebeer Leebouapao, Sthabandith Insisienmay and Vanthana Nolintha (2012) focused on ASEAN-China free trade and discussed the competitiveness of local industry in Laos. They found that the competitiveness of wood processing and cement industries based on price and product quality would be affected by the removal of tariffs. To maintain the domestic market and expand foreign markets, promoting product equality would be of great significance. For a FDI-led industry like motorcycle assembly, price competitiveness would not be affected significantly. OH. Jeong-Soo and Phuphet Kyophilavong (2013) used a standard Global Trade Analysis Project (GTAP) model to analyze the impact of ASEAN-Korean FTA on poverty in Laos. The article showed that Laos would gain benefits from ASEAN-Korean FTA like increasing GDP and domestic Welfare, moreover, the income of unskilled labor would be raised and also income distribution in Laos would be improved. 


\subsection{Gravity Model}

In the 1960s, quantitative research on international trade concentrated on trade flow. Jan Tinbergen (1962) used a simplified model and time series data to test the effect of each variable on trade flow in the gravity model. Later, Poyhonen.P (1963) used cross-sectional data to analyze international trade flow regressed on a gravity model. Hans Linnemann(1966) summarized the relevant research by using a gravity model to do trade flow analysis and firstly built a comprehensive framework to constructing a gravity model from theoretical and methodological aspects.

In 1970s, the gravity model developed significantly, forming four main research perspectives on the exploitation and application of gravity model: (1) Law of universal gravitation. The trade flow from $i$ country to $j$ country depends on the potential trade volume divided by obstructions or distance. Generally, geographical close countries tend to have large trade flow; (2) Walrasian Equilibrium Model. In this model, given a specific supply function and demand function of all goods, aggregate national income is used to represent the demand of the import country and supply of the export country while distance is transportation cost. According to the related researches of Norman Aitken .D (1973), Robert S. Obutelewicz (1976), Vincent J.Geraci \& Wilfried Prewo (1977), national income and distance had a significant impact on trade flow and statistically there is a negative correlation between population and trade flow. However, other researchers have shown different conclusions: there was a negative correlation between the national income of the export country and trade flow Herbert Glejser, (1968); population and trade flow were correlated positively Josef C.Brada \& Jose A.Mendez, (1983); (3) Probability theory. Edward E.Leamer \& Robert M.Stern (1971) believed that an import country trades with an export country randomly; (4) James E. (1979) improved the gravity model through a micro approach based on homogeneous preferences assumption in linear expenditure system.

In 1980s, the concentration of the gravity model had transformed from equation to variables. Considering the decisive role of supply and demand, Jeffrey H.Bergstrand (1985) pointed out that defining price as an endogenous variable ignored its critical value in the gravity model. Crockett Andrew and Morris Goldstein (1987) took the exchange rate and price into consideration.

Recently, many scholars have constantly applied the gravity model into international trade by using different variables and improved equations. Philippe Baccetta and Eric Van Wincoop (2003) emphasized the critical role of price the factor and put forward an equation with multilateral optimal pricing strategies. Later, the gravity model was widely used to examine the impact of the FTA. 


\section{An Overview of Laos' Economy}

Laos' population reached approximately 6.65 million in 2012. Table 1 summarizes the major economy indicators in Laos in the period of 1990-2012. In the past 22 years, the average annual GDP growth of Laos has become over 6.5\% and it's noticeable during 2006 and 2012, with an average growth of over 7.5\% annually. At the same time, GDP has rapidly increased from 856.56 million US\$ in 1990 to 9386.91 million US\$ in 2012, and GDP per capita has reached 1,412US\$ in 2012.

\section{Table 1.}

Major Economy Indicators in Laos

\begin{tabular}{lccccc}
\hline \multicolumn{1}{c}{ Description } & 1995 & 2000 & 2005 & 2010 & 2012 \\
\hline GDP (current US\$ million) & $1,763.54$ & $1,731.20$ & $2,735.55$ & $7,181.44$ & $9,386.91$ \\
GDP per capita (current US\$) & 362 & 321 & 475 & 1,123 & 1,412 \\
GDP annual growth (\%) & 7.03 & 5.80 & 7.11 & 8.53 & 8.20 \\
Export (\% of GDP) & 23.22 & 30.10 & 34.16 & 35.54 & 36.24 \\
Import(\% of GDP) & 37.33 & 44.21 & 46.50 & 37.91 & 48.44 \\
FDI (current US\$ million) & 95.10 & 33.89 & 27.72 & 278.81 & 294.38 \\
Inflation annually (\%) & 19.59 & 25.08 & 7.17 & 5.98 & 4.26 \\
Agriculture / GDP (\%) & 55.68 & 45.17 & 36.18 & 32.75 & 27.98 \\
Industry/ GDP (\%) & 19.24 & 16.61 & 24.61 & 31.80 & 36.21 \\
Service/ GDP (\%) & 25.08 & 38.23 & 39.21 & 35.45 & 35.81 \\
Population (Million people) & 4.87 & 5.39 & 5.79 & 6.40 & 6.65 \\
\hline
\end{tabular}

Source: The World Bank database.

In 1990, the economy of Laos was mostly based on traditional agriculture, the agricultural sector accounted for $61.23 \%$ of GDP, while the industry sector accounted $14.51 \%$ and $24.26 \%$ in the service sector. According to the data of GDP composition, it's noticeable that the industrial and service sector have gradually gained more energy with increasing proportions in GDP. In 2012, the proportion of the industrial and service sector in Laos GDP has reached $36.21 \%$ and $35.81 \%$ respectively while agriculture has decline to $27.98 \%$. 


\subsection{Trade Liberalization}

Economic and trade reforms in Laos can be classified into three periods: closed economy with central control (1975-1985); transition to a market-oriented economy (1986-2000); and an open economy with current policies (2000 onward) (Douangboupha, 2010; Souksavanh Vixathep, 2011). The study on the effect of the AFTA on the international trade in Laos was mostly in the end of the second period when Laos has been a member of ASEAN and participated AFTA.

A noticeable progress in trade liberalization in Laos was realized by the country becoming an ASEAN member in July 1997 and attended the AFTA in January 1998. Under AFTA, Laos had to complete the Common Effective Preferential Tariff (CEPT) scheme, meaning Laos had to reduce tariffs on manufactured and processed agricultural products to $0-5 \%$ by 2008 . Thus, the tariffs on many import commodities were significantly reduced and the import quota system of protecting local producers terminated.

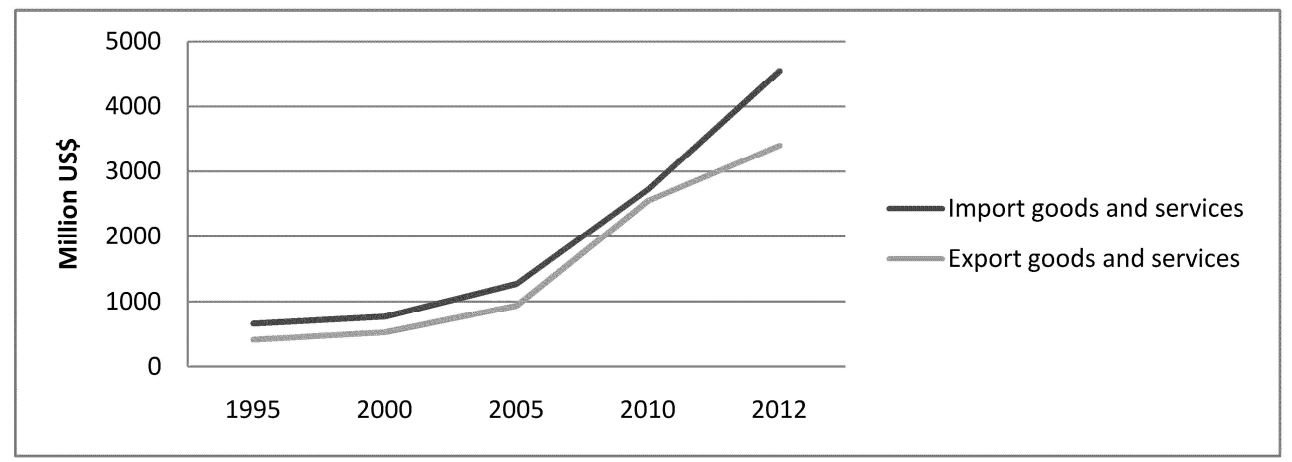

Source: The World Bank

\section{Figure1.}

Total Import and Exports of Laos (Current US\$ million)

Laos has been faced with a trade deficit for more than 15 years. During 1995 and 2000, the international trade of Laos has steadily increased from 3.06 billion US\$ in 1995 to 3.29 billion US\$ in 2000 and has maintained a trade deficit of no more than 300 million US\$(Figure 1). After joining ASEAN and practicing the CEPT scheme under AFTA, international trade in Laos was boosted in both import and export. The value of export was nearly 0.93 billion US\$ and import was over 1.27 billion US\$ in 2005. Later during 2005 and 2010, Laos reached the highest developing stage with significant increase in import and export of goods and services which have grown very fast with an average rate of 193\% in 
2010 compared to the year 2005. The growth rate of export began to slowdown compared with import in the period of the year 2010 to 2012 when Laos had the trade deficit of more than 1.15 billion US\$ in 2012.

\subsection{The Structure of International Trade in Laos}

\subsubsection{Region and Commodity Composition of Import}

ASEAN and China have been the main suppliers for Laos, followed by EU and partner countries in East Asia (Table 2). Particularly, ASEAN has maintained a share of more than $60 \%$ over the last decade. China also maintained the high share of about $10 \%$ during the year 1995 to 2005 and rapidly increased to $21.60 \%$ in 2012. In 1995, Japan, the EU and Australia had considerable percentage share with the value of $5.01 \%, 5.16 \%$ and 3.63 respectively. However, only Japan and the EU still maintained a high share in 2012, especially the share of the EU reached $10.90 \%$ while Australia has only a $0.50 \%$ share.

\section{Table 2.}

Region Compositions of Imports (\% share of total)

\begin{tabular}{lccccc}
\hline \multicolumn{1}{c}{ Trade partners } & $\mathbf{1 9 9 5}$ & $\mathbf{2 0 0 0}$ & $\mathbf{2 0 0 5}$ & $\mathbf{2 0 1 0}$ & $\mathbf{2 0 1 2}$ \\
\hline ASEAN & 70.52 & 54.64 & 79.27 & 85.59 & 60.30 \\
China & 8.52 & 15.73 & 9.13 & 9.70 & 21.60 \\
Hong Kong & N.A. & 0.00 & 0.75 & 0.00 & 0.00 \\
Japan & 5.01 & 0.19 & 4.17 & 0.39 & 2.4 \\
Korean (South) & n.a & 0.84 & 0.73 & 1.87 & 1.9 \\
Taiwan & N.A. & 0.07 & 0.76 & 0.00 & 0.00 \\
India & N.A. & 0.01 & 0.19 & 0.08 & 0.20 \\
EU & 5.16 & 0.56 & 3.85 & 0.73 & 10.90 \\
Norway & N.A. & 0.01 & 0.01 & 0.00 & 0.00 \\
Russia & N.A. & 0.03 & 0.23 & 0.00 & 0.10 \\
Switzerland & N.A. & 0.07 & 0.09 & 0.00 & 0.00 \\
Canada & N.A. & 0.01 & 0.01 & 0.04 & 0.80 \\
USA & N.A. & 0.24 & 0.55 & 0.11 & 0.40 \\
Australia & 3.63 & 0.06 & 0.22 & 0.18 & 0.50 \\
New Zealand & N.A. & 0.00 & 0.00 & 1.04 & 0.10 \\
Rest of the world & 7.16 & 27.53 & 0.03 & 0.27 & 0.80 \\
\hline Sows: conplicas
\end{tabular}

Sources: compiled by author; Ministry of industry and commerce of Laos, Laos Statistical Year Book, SouksavanhVixathep (2011).

Note: "N.A." indicated that data were unavailable; Figure 0.00 was the value less than 0.01 . 
Table 3 presents the commodity composition of imports. It is obvious that most of Laos' imports are material inputs, equipment and fuels for production. The country's imports mainly consist of petroleum oils, textile yarn and fabrics, non-metallic minerals, iron and steel, machinery and industrial machines, electrical machines, and road vehicles. Among consumer goods, beverages show a higher share. The highest percentage share of commodities is machinery and transport equipment with a share of $40.63 \%$ and followed by $25.87 \%$ of mineral fuels and lubricants in 2012 .

\section{Table 3.}

Commodity Composition of Imports ( $\%$ share of total)

\begin{tabular}{lccccc}
\hline \multicolumn{1}{c}{ (SITC) Description } & $\mathbf{1 9 9 5}$ & $\mathbf{2 0 0 0}$ & $\mathbf{2 0 0 5}$ & $\mathbf{2 0 1 0}$ & $\mathbf{2 0 1 2}$ \\
\hline (0): Food and live animals & 8.68 & 6.89 & 9.30 & 6.02 & 5.13 \\
(1): Beverages and tobacco & 8.88 & 6.85 & 0.64 & 5.12 & 1.34 \\
(2): Crude materials, inedible, except fuels & 0.25 & 2.38 & 0.46 & 0.50 & 0.77 \\
(3): Mineral fuels, lubricants & 7.83 & 11.70 & 13.50 & 25.29 & 25.87 \\
(4): Animal and vegetable oils and fats & 0.26 & 0.28 & 0.38 & 0.21 & 0.04 \\
(5): Chemicals and related products, n.e.s. & 6.53 & 6.39 & 10.92 & 6.82 & 5.84 \\
(6): Manufactured goods (class. by material) & 21.62 & 22.94 & 18.23 & 17.67 & 14.44 \\
(7): Machinery and transport equipment & 35.27 & 35.85 & 40.85 & 30.84 & 40.63 \\
(8): Miscellaneous manufactured articles & 6.11 & 4.92 & 4.72 & 3.41 & 5.75 \\
(9): Other commodities and transactions & 4.62 & 1.67 & 0.98 & 4.13 & 0.19 \\
\hline
\end{tabular}

Sources: Compiled by author; Department of Economic Statistics, Ministry of Finance of Laos; SouksavanhVixathep (2011).

\subsubsection{Region and Commodity Composition of Export}

With regard to export destinations, Laos' leading export markets are ASEAN and Australia which occupied about $67.20 \%$ and $20.50 \%$ of the Laos exports in 2012 respectively (Table 4). Other major partners are some EU member countries, China and Japan. Since trade data of the EU is only available consisting of France, UK, Germany, Netherlands, and Italy in 1995, however the sum to these countries still covers a high percentage share of $38.04 \%$. 


\section{Table 4.}

Region Compositions of Imports ( $\%$ share of total)

\begin{tabular}{|c|c|c|c|c|c|}
\hline Trade partners & 1995 & 2000 & 2005 & 2010 & 2012 \\
\hline ASEAN & 29.34 & 51.53 & 67.20 & 55.43 & 67.20 \\
\hline China & 2.71 & 4.25 & 4.63 & 3.27 & 6.40 \\
\hline Hong Kong & N.A. & 0.61 & 0.00 & 0.13 & 0.00 \\
\hline Japan & 12.45 & 1.05 & 0.78 & 2.67 & 2.30 \\
\hline Korean (South) & N.A. & 0.77 & 0.32 & 0.09 & 0.10 \\
\hline Taiwan & N.A. & 0.37 & 1.49 & 0.08 & 0.00 \\
\hline India & N.A. & 0.09 & 0.01 & 0.01 & 0.00 \\
\hline $\mathrm{EU}$ & 38.04 & 28.91 & 14.14 & 8.88 & 2.80 \\
\hline Norway & N.A. & 1.16 & 0.01 & 0.00 & 0.00 \\
\hline Russia & N.A. & 0.01 & 0.01 & 0.03 & 0.00 \\
\hline Switzerland & N.A. & 0.78 & 0.01 & 0.85 & 0.00 \\
\hline Canada & N.A. & 0.62 & 0.41 & 0.19 & 0.00 \\
\hline USA & N.A. & 1.74 & 0.37 & 2.11 & 0.00 \\
\hline Australia & 0.05 & 0.04 & 10.55 & 24.76 & 20.50 \\
\hline New Zealand & N.A. & 0.01 & 0.00 & 0.05 & 0.00 \\
\hline Rest of the world & 17.41 & 8.06 & 0.07 & 1.44 & 0.70 \\
\hline Total (\%) & 100 & 100 & 100 & 100 & 100 \\
\hline
\end{tabular}

Sources: compiled by author; Ministry of industry and commerce of Laos, Laos Statistical Year Book, Souksavanh Vixathep (2011).

Note: "N.A." indicated that data were unavailable; Figure 0.00 was the value less than 0.01

It can also be observed that in the year between 1995 and 2000 exports of miscellaneous manufactured goods (SITC 8) increased remarkably and have made up a large portion of exports since then. In 2012, Table 5 also reveals another interesting issue namely a sharp increase in food and live animals category (SITC 1) and basic manufactured goods (SITC 6) with the share of $26.28 \%$ and $50.92 \%$ respectively. On the other hand, the crude material, inedible, except fuels (SITC 2) decreased from $40.49 \%$ to $11.47 \%$. 
Table 5.

Commodity Composition of Exports ( $\%$ share of total)

\begin{tabular}{lccccc}
\hline \multicolumn{1}{c}{ (SITC) Description } & $\mathbf{1 9 9 5}$ & $\mathbf{2 0 0 0}$ & $\mathbf{2 0 0 5}$ & $\mathbf{2 0 1 0}$ & $\mathbf{2 0 1 2}$ \\
\hline (0): Food and live animals & 10.14 & 7.33 & 25.21 & 19.12 & 16.28 \\
(1): Beverages and tobacco & 0.41 & 0.06 & 1.25 & 1.37 & 0.21 \\
(2): Crude materials, inedible, except fuels & 40.49 & 33.94 & 14.31 & 31.62 & 11.47 \\
(3): Mineral fuels, lubricants & 0.25 & 0.40 & 22.53 & 0.87 & 0.77 \\
(4): Animal and vegetable oils and fats & 0.00 & 0.00 & 0.00 & 0.00 & 0.00 \\
(5): Chemicals and related products, n.e.s. & 1.74 & 0.04 & 0.33 & 1.18 & 2.74 \\
(6): Manufactured goods (class. by material) & 8.68 & 1.21 & 33.74 & 26.86 & 50.92 \\
(7): Machinery and transport equipment & 0.26 & 18.16 & 1.44 & 1.40 & 0.13 \\
(8): Miscellaneous manufactured articles & 37.45 & 36.81 & 0.11 & 11.10 & 0.43 \\
(9): Other commodities and transactions & 0.30 & 0.30 & 1.10 & 6.47 & 17.04 \\
\hline
\end{tabular}

Sources: Compiled by author; Department of Economic Statistics, Ministry of Finance of Laos; Souksavanh Vixathep (2011).

\section{Economic Model, Sources of Data and Variable Measurement.}

\subsection{Variable Selection and Explanation}

Considering data availability, the study period of this paper is 13 years from 2000 to 2012. With reference to the gravity model mentioned above, variables in the economic model of trade flow in Laos are: (1) Gross domestic product of Laos and trading countries; (2) foreign direct investment; (3) size of economy of AFTA; (4) the economic structure similarity between Laos and trading countries; (5) the AFTA binary variable, (6) the distance between Laos and trading countries; (7) the language similarity between Laos and trading countries.

Therefore, the econometric model for this paper is:

$$
\begin{aligned}
\ln T R A D E_{l i t}= & \alpha_{0}+\alpha_{1} \ln G D P_{l t}+\alpha_{2} \ln G D P+\alpha_{3} F D I_{l t}+\alpha_{4} \ln S E A_{l i t}+(1) \\
& \alpha_{5} \ln E S S_{l i t}+\alpha_{6} D_{l i t}+\alpha_{7} \ln D I S T_{l i}+\alpha_{8} \ln L A N G_{l i}+\mu_{l i t}
\end{aligned}
$$

Where $l$ is Laos, $t$ is time period (year), $i$ is trade partner countries, $\mu_{l i t}$ is error terms. 
In equation (1), TRAED $D_{l i t}$ denotes the total trade flow between Laos and the country $i$ in the year $t$, it's the sum of export and import of Laos and country $i$ in the year $t$. Data sources come from the ministry of industry and commerce of Laos. In this paper, 29 main trade partners with Laos around the world are chosen.

$G D P_{l t}$ and $G D P_{j t}$ represent the market scales of trading countries, reflecting the potential purchasing power of international economic trade. The overall market scale of the import country and export country would affect the trade volume once the free trade agreement is settled, due to the following reasons: (1) Improving terms of trade. The larger the market scale is, the bigger the demand elasticity of goods outside the free trade area could be. Thus, the terms of trade could possibly become favorable to the country within the free trade area and economic profits tend to increase. (2) Bringing the trade creation effect. A Large market scale means a wide range of the country joining international specialization. (3)Reducing the production cost. A large market scale enables scale production. Therefore, production cost should be cut down significantly. In the meanwhile, given the other conditions of trade, larger market scale would weaken trade transfer effect. The source of data is from World Bank Database. As a prediction, the coefficient of GDP and $G D P_{j t}$ would be positive.

$F D_{l t}$ denotes the FDI inflow into Laos in the year $t$. This data source is from the World Bank database. The relationship between FDI and trade isn't a new topic for discussion among international trade researches, Mundell (1975) proved that FDI was able to substitute import and import would decrease if FDI increased. Later, Krugman (1991)pointed out that FDI and trade have a substituted relationship. While Blonigen (1997b) had a different opinion, the empirical work showed that the relationship between FDI and trade was found to be complementarity. Thus, it can be summarized that the relationship between FDI and Trade are: (1) FDI and trade is substitution, (2) FDI and trade is complementarity. We select this explanatory variable in the econometric model of this paper to see how FDI affects the international trade flow in Laos.

$S E A_{i t}$ denotes the size of economy of AFTA in the year $t$. Neo-classical trade theory predicts that large countries tend to be net exporters in scale-intensive industries (Helpman and Krugman, 1985); Krugman and Venables, 1995).Large economy size of AFTA reflects plenty memberships, wide variety of commodity, strong purchasing power, large market demand and supply which could certainly benefit each membership within the free trade zone. Thus, the size of the economy of AFTA $\left(S E A_{i t}\right)$ is chosen to be one of the explanatory variables to measure the impact of international trade flow in Laos. The larger the size of the economy is, the stronger the driving effects could be. The calculation of this variable is to sum all real GDP of all membership and the other AFTA trade dialogue 
partner countries in the year $t$, excluding Laos. And the source of data is from World Bank Database.

$E S S_{l i t}$ denotes the economic structure similarity between Laos and $j$ country in the year $t$. According to the theory, the coefficient of ESS should be negative due to the following reasons: (1) Similar industrial structure neglects the importance of international specialization. International trade would not happen if all countries produce the same commodities; (2) a similar industrial structure may trigger fierce competition and local protectionism since every country would like to protect their own industry. The calculation method of this variable is to find the similarity of the GDP sector composition, the percentage of agriculture, industry and service, between Laos and other countries by using the similar coefficient of industrial structure presented by the United Nations Industrial Development Organization (UNIDO) in 1979. The economic structure similarity is:

$$
S_{l i}=\frac{\sum_{m=1}^{k} x_{l m} x_{i m}}{\sqrt{\sum_{m=1}^{k} x^{2_{l m}} \sum_{m=1}^{k} x^{2_{i m}}}} 0 \leq S_{l i} \leq 1
$$

Where $S_{l i}$ refers to the economic structure similarity of two countries $l$ and $i, x_{l m}$ represents the proportion of GDP sector composition $\mathrm{m}$ in $l$ country, $x_{l m}$ represents the proportion of GDP sector composition $m$ in $i$ country. The value of $S_{l i}$ is between 0 and 1 . If $S_{l i}=0$, it means that the economic structure similarity in $l$ country and $i$ country is totally different, if $I F S_{l i}=1$, it means that the economic structure similarity in $l$ country and $i$ country is totally the same.

$D_{l i t}$ denotes the general effects of AFTA and its binary variable which is one of country $i$ and country $l$ belong to the AFTA membership in $t$ year or otherwise given zero. This explanatory binary variable is to explain how AFTA affects international trade between Laos and the trading partner countries. In this case, we assume that the coefficient of the binary variable $D_{\text {lit }}$ is positive meaning that the AFTA conduced the increasing of trade flow in Laos and reverse if the coefficient of $D_{l i t}$ is negative.

DIST represents the geographical distance between Laos and $i$ country. It is the real distant in kilometer between the capital city of Laos and the capital city of $i$ country. Short distance contributes to lower transportation cost and reduces production cost in scale production when other conditions are settled. Besides, geographical proximity also reflects similar preference, mutual benefit and coordinated policy, resulting in positive trading 
effect. Thus, the coefficient of DIST ${ }_{l i}$ should be negative. Source of data is from the CEPII database.

$L A N G_{l i}$ measures the language similarity between Laos and country $i$. Most literatures have used dummy variables to represent language similarity(Shujiro Urataand Misa Okabe, 2007; Edward Zhu,2013), but a dummy variable would fail to figure out the exact similarity level. Thus, we try to calculate the exact probability that randomly selected people between Laos and other countries could communicate under the same language. Considering limited data acceptability and the fact that language similarity seldom changes around the research period, we assume the variable $L A N G_{l i}$ is constant. Laos surrounded by five neighbor countries, in these five countries there are the ethnic groups which are the same ethnic groups in Laos. In fact, most of Laos' trading partner countries didn't have the same language with Laos except five neighbor countries. Thus, English proficiency index is also used to measure language similarity by calculating English proficiency of every country. The variable $L A N G_{l i}$ is the sum of communication possibility plus English proficiency index. Obviously, the coefficient of $L A N G_{l i}$ should be positive. Sources of data are from the CEPII database and English Proficiency Index (EF EPI). Below is the calculation method of $L A N G_{l i}$ :

$$
L A N G_{l i}=\sum_{m=1}^{k} \text { Percent }_{l a n g, n, 1} * \text { Percent }_{\text {lang }, n, i}+\text { EFEPI }
$$

Where Percent lang,,$l_{l}$ is the percent who speak $n$ language in Laos, Percent lang,,$i$ is the percent who speak $n$ language in $i$ country and EFEPI is the English proficiency index.

\subsection{Model Adjustment}

After many attempts to estimate the equation (1) above, the outcome of the estimation didn't give the ideal result, some of explanatory variables were not significant. Actually, we found that this problem occurred due to the fact that some variables represent the effect of the same factor on international trade which may create the risk of collinearity. Thus, several adjustments are made as below: 


\subsubsection{GDP $P_{l t}$ and $G D P_{i t}$}

$G D P_{l t}$ and $G D P_{\text {it }}$ both are the variables representing the market scale. Indeed, it doesn't make sense to separate these two variables, because in the free trade area, the memberships are in the same market scale. Similarly, this is the same point made by the econometric analysis, these two variables are trying to predict the same effect to the explanatory variable. Finally, as it turned out, we were able to get a better result by multiplying these two variables together to be a new explanatory variable $M S_{l i t}$ (Market Scale).

\subsection{2 $D_{I S T}$ and $L A N G_{l i}$}

As a matter of fact, both language similarity and distance between import country and export country could measure the effect of the cultural factor on international trade which may increase the risk of collinearity and weaken model explanatory power. Considering the positive effect of language similarity and the negative effect of distance, we multiply $D I S T_{l i}$ and the reciprocal of $L A N G_{l i}$ to get a new explanatory variable, called cultural barrier $\left(\mathrm{CulBar}_{l i}\right)$. The combined explanatory variable will have more power in explaining the effect of cultural factors than separating it, it is supposed to have a negative effect on international trade after reasonable adjustment. Therefore, the $\mathrm{CulBar}_{l i}$ is chosen to represent the impact of cultural factors on international trade in the model.

\subsubsection{Extended Explained Variables}

To discuss the impacts of every explanatory variable on the international trade deeply, we separated the trade volume into import and export and built three equations. In this case, the specific impacts of those explanatory variables on international trade could be tested separately. The effect of some variable on international trade doesn't mean that it has the same effect on both import and export. For example, assume that one explanatory variables has a positive effect on international trade volume, but it may have a positive effect on import while having a negative effect on export or vice versa. Thus, the detailed impact of each variable on international trade could be tested separately through the following three equations:

$$
\ln T R A D E_{l i t}=\alpha_{0}+\alpha_{1} \ln M S_{l i t}+\alpha_{2} F D I_{l t}+\alpha_{3} \ln S E A_{l i t}+\alpha_{4} \ln E S S_{l i t}+\alpha_{5} D_{l i t}+\alpha_{6} \operatorname{CulBar}_{l i}+\mu_{l i t}
$$




$$
\begin{aligned}
& \ln I M P O R T_{l i t}=\alpha_{0}+\alpha_{1} \ln M S_{l i t}+\alpha_{2} F D I_{l t}+\alpha_{3} \ln S E A_{l i t}+\alpha_{4} \ln E S S_{l i t}+\alpha_{5} D_{l i t}+\alpha_{6} \operatorname{CulBar}_{l i}+\mu_{l i t} \\
& \ln E X P O R T_{l i t}=\alpha_{0}+\alpha_{1} \ln M S_{l i t}+\alpha_{2} F D I_{l t}+\alpha_{3} \ln S E A_{l i t}+\alpha_{4} \ln E S S_{l i t}+\alpha_{5} D_{l i t}+\alpha_{6} \operatorname{CulBar}_{l i}+\mu_{l i t}
\end{aligned}
$$

Where $\alpha_{0}$ is intercept and $\alpha_{1}, \alpha_{2}, \alpha_{3}, \alpha_{4}, \alpha_{5}$ and $\alpha_{6}$ are the coefficients that measure the TRADE affect with respect to the variables of $M S, F D I, S E A, E S S, D$ and CulBar, respectively.

\section{Table6.}

The Expected Coefficient of Explanatory Variables

\begin{tabular}{ccccccc}
\hline Explanatory variable & $M S$ & FDI & SEA & ESS & D & CulBar \\
\hline Expected symbol & + & $?$ & + & - & $?$ & - \\
\hline
\end{tabular}

Note: “+" represent the positive effect, and "'-" represent the negative effect, "?" represent the uncertain effect.

\section{Result and Discussion.}

In this paper we applied the STATA 11.0 statistical software package for the regression. In this paper we use a feasible generalized least squares (FGLS) procedure that can deal with autocorrelation within panels and heteroskedasticityacross panels Greene (2000). The result of estimating under the model FGLS method showed in the Table 7 below. In Equation (4), (5)' and (6)", all of the coefficient of explanatory variable are significant at least at the $10 \%$ significant level. The Wald chi-square estimate proves that the equation (4), (5)' and (6)" has fitted the data well, and there are no problems with the collinearity of explanatory variables.

Table 7.

\begin{tabular}{|c|c|c|c|c|c|c|}
\hline Variable & (4) & (5) & (5)' & (6) & (6)' & (6)" \\
\hline$M S$ & $\begin{array}{c}0.282 \\
\left(\begin{array}{l}0.032 \\
* * *\end{array}\right)\end{array}$ & $\begin{array}{c}0.951 \\
\left(\begin{array}{l}0.500 \\
*\end{array}\right)\end{array}$ & $\begin{array}{c}0.993 \\
\left(\begin{array}{l}0.496 \\
* *\end{array}\right)\end{array}$ & $\begin{array}{c}1.911 \\
\left(\begin{array}{l}0.488 \\
* * *\end{array}\right)\end{array}$ & $\begin{array}{c}1.759 \\
\left(\begin{array}{l}0.383 \\
* * *\end{array}\right)\end{array}$ & $\begin{array}{c}1.685 \\
\left(\begin{array}{l}0.380 \\
* * *\end{array}\right)\end{array}$ \\
\hline$F D I$ & $\begin{array}{c}-0.079 \\
\left(\begin{array}{l}0.030 \\
* * *\end{array}\right)\end{array}$ & $\begin{array}{c}-0.626 \\
(0.456)\end{array}$ & & $\begin{array}{c}0.205 \\
(0.437)\end{array}$ & & \\
\hline
\end{tabular}

Result of the estimation under the FGLS method 


\begin{tabular}{|c|c|c|c|c|c|c|}
\hline Variable & (4) & (5) & $(5)^{\prime}$ & (6) & (6)' & (6)" \\
\hline$S E A$ & $\begin{array}{c}0.534 \\
\left(\begin{array}{l}0.039 \\
* * *\end{array}\right)\end{array}$ & $\begin{array}{c}1.472 \\
\left(\begin{array}{l}0.602 \\
* *\end{array}\right)\end{array}$ & $\begin{array}{c}0.734 \\
\left(\begin{array}{l}0.288 \\
* *\end{array}\right)\end{array}$ & $\begin{array}{c}-0.380 \\
(0.577)\end{array}$ & & \\
\hline ESS & $\begin{array}{c}1.711 \\
\left(\begin{array}{l}0.183 \\
* * *\end{array}\right)\end{array}$ & $\begin{array}{c}6.403 \\
\left(\begin{array}{l}2.816 \\
* *\end{array}\right)\end{array}$ & $\begin{array}{c}0.671 \\
\left(\begin{array}{l}2.755 \\
* *\end{array}\right)\end{array}$ & $\begin{array}{c}5.363 \\
\left(\begin{array}{l}2.700 \\
* *\end{array}\right)\end{array}$ & $\begin{array}{c}4.551 \\
\left(\begin{array}{l}2.204 \\
* *\end{array}\right)\end{array}$ & $\begin{array}{c}0.514 \\
\left(\begin{array}{l}2.160 \\
* *\end{array}\right)\end{array}$ \\
\hline$D$ & $\begin{array}{c}0.032 \\
\left(\begin{array}{l}0.015 \\
* *\end{array}\right)\end{array}$ & $\begin{array}{c}-0.115 \\
(0.236)\end{array}$ & & $\begin{array}{l}-0.482 \\
\left(\begin{array}{l}0.006 \\
* *\end{array}\right)\end{array}$ & $\begin{array}{c}-0.493 \\
\left(\begin{array}{l}0.225 \\
* *\end{array}\right)\end{array}$ & $\begin{array}{l}-0.456 \\
\left(\begin{array}{l}0.223 \\
* *\end{array}\right)\end{array}$ \\
\hline CulBar & $\begin{array}{c}-0.053 \\
\left(\begin{array}{l}0.028 \\
*\end{array}\right)\end{array}$ & $\begin{array}{c}-1.103 \\
\left(\begin{array}{l}0.426 \\
* * *\end{array}\right)\end{array}$ & $\begin{array}{c}-1.104 \\
\left(\begin{array}{l}0.425 \\
* * *\end{array}\right)\end{array}$ & $\begin{array}{c}-0.567 \\
(0.408)\end{array}$ & $\begin{array}{c}-0.500 \\
(0.391)\end{array}$ & \\
\hline Constant & $\begin{array}{c}0.540 \\
\left(\begin{array}{l}0.321 \\
*\end{array}\right) \\
\end{array}$ & $\begin{array}{l}-14.698 \\
\left(\begin{array}{l}4.937 \\
* * *\end{array}\right) \\
\end{array}$ & $\begin{array}{l}-10.676 \\
\left(\begin{array}{l}3.733 \\
* * *\end{array}\right) \\
\end{array}$ & $\begin{array}{c}-1.593 \\
(4.732) \\
\end{array}$ & $\begin{array}{c}-3.716 \\
(3.369) \\
\end{array}$ & $\begin{array}{c}-5.098 \\
(3.198) \\
\end{array}$ \\
\hline Wald chi2 & 1607.69 & 53.29 & 50.89 & 32.79 & 32.26 & 30.50 \\
\hline$p$-Value & 0.0000 & 0.0000 & 0.0000 & 0.0000 & 0.0000 & 0.0000 \\
\hline
\end{tabular}

Note: ***, ** and * indicate that the estimated coefficients are statistically significant at $1 \%, 5 \%$ and $10 \%$, respective

\subsection{Explanatory Variables}

\subsubsection{Trade}

The result of equation (4) in Table 7 shows, MS has positive effect on TRADE. TRADE would increase $2.82 \%$ with a10\%increase in MS. It means that a larger market scale contributes to higher trading volumes. Since larger MS brings more trading opportunities and comes with larger demand and supply, resulting in the increase of import and export volume between Laos and trade partners.

The negative effect of foreign direct investment means there has to be substituted relationship between trade and foreign direct investment. Here, the coefficient of FDI is -0.079 , which means that it is consistent with Lao economy. In early $2000 \mathrm{~s}$, electricity was not available in many areas in Laos and some provinces had to import electricity from neighbor countries. In addition, people are still doing traditional farming with low production efficiency which can't meet domestic market demand. According to the statistic, during the past decade the main sectors of FDI in Laos were mining, hydropower and 
agriculture which can reduce some major import commodities like food and electricity from other countries and these are reasons why FDI has a negative effect on TRADE.

As for the size of economy of AFTA, this variable has a significant positive effect on international trade in Laos. In column (4) of Table 7, 10\% increase in SEA would result in $5.34 \%$ increase in TRADE. Considering the measurement of this variable, we can also use this variable to examine the integration level of AFTA, high integration level causes low trade barrier among memberships and is advantageous to increasing trade flow inside AFTA. Consequently, we conclude that the explanatory variable SEA has sufficient power to reflect the impact of AFTA on international trade flow.

According to Table 6, the expected coefficient for the variable ESS should be negative, but the result in Table 7 showed that ESS has positive effect on TRADE. ESS increasing 10\% will cause TRADE increasing 17.71\%. It's obviously that ESS has the greatest effect on TRADE which opposes to the idea that trade flow tends to decline if two countries have a high percent of economic structure similarity due to high competition and local protectionism. The following context might answer why the effect of ESS is negative. Firstly, due to the limited data acceptability, we used the overall data of agriculture, industry and service sectors instead of detailed data within industry to calculate the ESS, leading to less accuracy of ESS. Secondly, although high ESS would bring high competition and local protectionism, Laos has a weak industrial foundation and most necessary commodities rely on import, meaning that Laos does not have the intention and capability to compete with trading partners. Finally, the ESS between Laos and major trade partner countries are relatively low and the similar level of ESS is not high enough to create competition. Therefore, the outcome resist the expected coefficient in Table6.

Consistent with our expectation, the coefficient of the binary variable $\mathrm{D}$ has a positive effect on international trade volume in Laos. International trade flow in Laos has increased after being a member of AFTA. The result proves that AFTA bring $0.032 \%$ increase in TRADE. Although the positive effect is relatively low, for new membership and weak economy nation likes Laos, this is a good start in the long term for the development of bilateral and multilateral trade in the regional integration plans of Laos in the future.

The effect of CulBar on international trade is as expected negative and significant. $10 \%$ increase in CulBar results in $0.53 \%$ decrease in TRADE. This result means that Laos is likely to trade more with neighbor countries rather than faraway countries. Indeed, the top three major trade partners of Laos (Thailand, China and Vietnam)all share a border with Laos. Among those, Thailand has many cultural factors that are similar with Laos like language, custom, religion and others, these similarities help to reduce culture barriers and promote trading with other neighbor countries. 


\subsubsection{IMPORT and EXPORT}

The regression results of IMPORT and EXPORT in Table 7 show the coefficients of the explanatory variables are almost similar with that of TRADE. But in the case of IMPORT and EXPORT, some insignificant variables are dropped in order to fit the model with the explanatory variables.

In the case of IMPORT, there are 2 dropped insignificant variables (FDI and D) and then we get the fit model to examine the effect of AFTA on IMPORT (Table 7, equation (5) '). Result of the equation (5)' shows that $10 \%$ increase in MS, SEA, ESS and CulBar result in $9.93 \%, 7.34 \%, 6.71 \%$ and $-11.04 \%$ increase in IMPORT respectively. Although, we dropped the binary variable $D$, we still have SEA that can explain how AFTA affects the import of Laos in the equation (5)'. Obviously, SEA has a positive effect on IMPORT, we can summarize that as meaning participating in AFTA would push Laos to import more commodities from abroad. AFTA could remove the tariff barrier and the larger size of economy of AFTA would promote Laos import.

As for EXPORT, we found that half of the explanatory variables are insignificant, after dropping FDI, SEA, and CulBar, we get equation (6)" with three explanatory variables remaining, MS, ESS and D. In the econometric views, MS has the highest coefficient in the equation (6)", $10 \%$ increase in MS and ESS would result in $16.85 \%$ and $5.14 \%$ increase in TRADE respectively. However, the variable to reflect the impact of AFTA has a significant negative effect with the coefficient of -0.456 which means that Laos' export would decrease $0.456 \%$ if participating AFTA. Laos has a serious trade deficit problem and export mostly relies on natural resources to balance the import and export. According to the data obtained from the Ministry of Industry and Commerce of Laos, in the past decade, the major export products of Laos are wood, mining and agriculture products. But in recent years, the Laos government reduced or quit the export quotas of wood and mining, this possibly explains why the coefficient of $\mathrm{D}$ is negative. Therefore, we have to drop half of explanatory variable to fit the model, we still can't prove whether the model gives us a reliable outcome.

\section{Conclusion}

This paper has sought to explain the effect of AFTA on international trade flow in Laos during 2000 and 2012.After discussing the result of the regression above, we can briefly summarize the result of the study, AFTA has a positive effect on the total trade flow 
and imports, but has a negative effect on exports in Laos.

Laos'aggregate international trade benefits from participating in AFTA since the two variables that reflect AFTA are significant positive generally. The size of the economy of AFTA plays an important role in increasing international trade flow in Laos which means AFTA brings more trading opportunities to the state. The binary variable $\mathrm{D}$ also proves that Laos will gain more benefits by joining AFTA.

However, AFTA stimulates import but has a negative effect on export in Laos. From the discussion of the model above, the coefficient of SEA, which is the only remaining variable that can reflect the effect of AFTA on import, has proved that AFTA has a positive effect on import in Laos. The results stay consistent with the theory that FTA brings advantages to the export of large countries rather than small countries(Krugman and Venables, 1995), which could be explained by the larger economy size of AFTA that increases import of small countries. The theory could also be used to explain why AFTA has a negative effect on export in Laos as the coefficient of the binary variable demonstrated. AFTA benefits large countries rather than small countries therefore joining AFTA brings a negative effect to export in small countries like Laos.

In spite of the negative effect on exports that AFTA has, however AFTA has an overall positive effect on aggregate international trade flow and import which means that the positive effect of AFTA is greater than the negative effect. Additionally, besides AFTA, there are many other factors like economic structure and cultural barrier that would cause the value of trade to increase or decrease.

\section{Acknowledgments}

The authors would like to thank the reviewers for their constructive comments on this paper. Any remaining errors are my own responsibility. 


\section{References}

Aitken .D (1973). The effect of the EEC and EFTA on European trade: A temporal cross-section analysis. American Economic Review, vol. 5, 881-889.

Bende-Nabende (1999). FDI, regionalism, government policy, and endogenous growth: A comparative study of the ASEAN-5 economies, with development policy implication for the least development countries. California university Ashgate.

Blonigen, Bruce A. September 1997b. In Search of Subsitution between Foreign Production and Export, mimeo. University of Oregon.

Crockett Andrew and Morris Goldstein (1987).Strengthening the International Monetary system: Exchange Rate, Surveillance and Objective Indicators. Occasional Paper No.50.

Douangboupha, L. (2010). Effects of trade policy reforms on economic growth: The case of Lao PDR. Lao Trade Research Digest, 1, 59-96.

Edward Zhu (2013). The Case for Free Trade Agreements: Historical Perspectives and a Projection for China, Japan, and Korea. Stanford University, honors thesis.

Edward E.Leamer\& Robert M. Stern(1971).Quantitative international Economic. Journal of Economic Literature, Vol.9.No.3, 944-846.

Greene, W. H. (2000). Econometric Analysis, Prentice Hall, New York, Fourth edition, international edition.

Future Strategic Directions for TSR and TCR from the Perspective of the Northeast Asian Logistics Network

Heo, Yoon and Tran N. Kien(2012), "Korea-ASEAN Trade Flows and the Role of AFTA: Sector-Specific Evidence of Trade Diversion", Journal of International Logistics and Trade, Volume 10, No. 2. 
Herbert Glejser, (1968). An explanation of difference in trade-product rations among countries. Cashiers econmiquesde Bruxelles, vol.37, 47-58.

Janamitra Devan (1987). An Inter-Country analysis of the ASEAN PTA: Ex Post and Ex Ante. Working Papers for International Economic relations: 322-335.

James E. Anderson (1979). A theoretical foundation for the gravity equation. American Economic Review, Vol.66.No.1, 106-16.

Jeffrey H.Bergstrand (1985). The Gravity equation in international trade: Some microeconomic foundations and empirical evidence. The Review of Economics and statistics, Vol.67.No.3, 474-81.

Josef C.Brada\& Jose A.Mendez, (1983).Regional economic integration and the volume of intra-regional trade: A comparison of developed and developing country experience. Kyklos, Vol.36, 589-603.

Junlin Li, Dongmin Yao and Xiaochen Xu (2012). Regional Economic Integration Of ASEAN: An Empirical Analysis based on National Border Effect. Economic Theory and Business Management, Vol.4, 102-112.

KeoVongxay (2006). The Impact Of AFTA On Laos Economy And Small Scale Producers. Southeast Asian Council For Food Security And Fair Trade, No.24.

Krugman, P. (1979). Increasing Returns, Monopolistic Competition, and International Trade. Journal of International Economics, Vol. 9 No.4, 469-479.

Krugman, P. and Helpman, E. (1985). Market Structure and International Trade, MIT Press.

Krugman, P. (1991). Increasing returns and economic geography. Journal of Political Economy, University of Chicago, Vol.99.No.3, 483-99.

Krugman P. and Venables Anthony J. (1995). Globalization and the inequality of Nations, The Quarterly Journal of Economics, Vol.110,No.4, 875-80.

Lee,Paul T-W, Tsung-Chen Lee and Tzu-Han Yang(2013), "Korea-ASEAN Free Trade Agreement: The Implications on Seaborne Trade Volume and Maritime Logistics 
Policy Development in Korea", Journal of International Logistics and Trade, Volume 11, No. 1.

Leebeer Leebouapao, Sthabandith Insisienmay and Vanthana Nolintha (2012). ASEANChina Free Trade Area and the Competitiveness of Local Industries: A Case Study of Major Industries in the Lao People's Democratic Republic. ADB Working Paper Series on Regional Economic Integration, No. 98.

Linnermann hans (1966). An econometric study of international trade flow. North-Holland Publishing company, Amsterdam. No. 42, 234.

Misa OKABE and Shujiro URATA (2013). The Impact of AFTA on Intra-AFTA Trade. ERIA Discussion Paper Series, May.

Mundell R. (1975). Factor mobility and international mobility. American Economic Review, Vol.47, 321-335.

Naya (1980). ASEAN Trade Development and Cooperation: Preferential Trading Arrangements and Trade Liberalization.: UNCTAD.

OH. Jeong-Soo and Phuphet Kyophilavong (2013). Impact of ASEAN-Korea FTA on Poverty: The Case Study of Laos. World Applied Science Journal 28, Economic, Finance and Management Outlooks, 114-119.

Peal Imada (1993). Production And Trade Effects Of An ASEAN Free Trade Area. Journal of The Developing Economies, Vol.31, No.1

Philippe Bacchetta and Eric van Wincoop(2003). why do customer prices react less than import prices to exchange rate?. Journal of the European Economic Association, Vol. 1.No.2-3, 662-670.

Phouphet KYOPHILAVONG (2004).Analyzing the effect of AFTA on Lao economy, Macroeconomic model approach. ESRI Asia Workshop on Economic Modeling on Deepening Interrelationships among Asian Countries, Bangkok, Thailand November 30. 
Poyhonen.P (1963).A tentative model for the volume of trade between countries. Weltwirtschaftliches Archiv: 90, 93-99.

Robert S. Obutelewicz (1976). Across-sectional Study of EEC trade with the association of African countries. The review of economics and statistic, Vol.58.4, 425-33.

Souksavanh Vixathep (2011). Trade Liberalization and Comparative Advantage Dynamics in Lao PDR. Lao Trade Research Digest, Vol.2

Tinbergen Jan (1962). An analysis of world trade flow, Shaping the world economy. New York: the Twentieth Century Fund, 271-273

Vincent J.Geraci \& Wilfried Prewo (1977).Bilateral trade flow and transport costs. The Review of Economic Statistic, vol.59.1,67-74.

Viner, J. (1950). The customs union issue. New York: Carnegie Endowment.

Yin Hua and Soulya Phoulaxavong (2012). The Impact of China-ASEAN Free Trade Area on Laos and China's Trade. Journal of Accounting and Finance, Vol.137, 27-32. 